\title{
EVALUATION OF SOLAR THERMAL DRIVEN COOLING SYSTEM IN OFFICE BUILDINGS IN SAUDI ARABIA
}

\author{
Majid T. Linjawi, Qazi Talal, Fahad A. Al-Sulaiman
}

\begin{abstract}
In this study solar driven absorption chiller is used to reduce the peak cooling load in office buildings in Saudi Arabia for different selected cities. The study is conducted for six cities of Abha, Dhahran, Hail, Jeddah, Nejran and Riyadh under three operating durations of 4, 6, and 8 hours using flat plate or evacuated tube collectors. The energy analysis concluded that flat plate collectors are better than evacuated tube collectors. However, the results from economic analysis suggest that while proposing a gas fired absorption chiller will reduce running costs, further reduction by using solar collectors is not feasible because of its high initial cost. At the best case scenario the Net Present Value of a 10 Ton Absorption chiller operated by natural gas boiler and two large flat plate collectors $\left(12 \mathrm{~m}^{\wedge} 2\right.$ each) running for 8 hours/day, 5days/week has a value of 117,000 \$ and Internal Rate of Return (IRR) of $12 \%$. Solar driven absorption chiller could be more feasible if the gas prices increases or the solar collector prices decreases significantly. Finally, government economic incentives and taxes are recommended to provide a boost for the feasibility of such projects.
\end{abstract}

Keywords: absorption chiller, solar cooling, energy analysis, economic analysis

\section{Introduction}

The growth in economy and advancement in technology depends on the amount of energy that is available and can be utilized in that country. Fossil fuels are the primary source of energy that is utilized in almost all places throughout the world. Nevertheless fossil fuels are a non-renewable source of energy and its resources are getting depleted. In addition, burning fossil fuel causes an adverse effect on the environment such as pollution, global warming and depletion of ozone layer due to the greenhouse gas effect. Hence the need arises to explore alternative sources of energy that reduces the burning of fossil fuels. In the present day renewable energy sources are the best alternative for supplying the required energy and decrease the combustion of fossil fuels. Examples of renewable energy include solar energy, wind energy, geothermal energy, tidal energy etc. Solar energy has the most potential among all these different types of energy because it's high availability in nature. At present the energy consumed by the world is about $1.84 \times 10^{13} \mathrm{~W}[1]$ and the amount of solar radiation that is transmitted to the earth is around $1.74 \times 10^{17} \mathrm{~W}[2]$. Hence solar energy has vast potential as an energy source. 
We cannot however completely eliminate utilization of conventional energy sources as it is currently impossible, but the focus should be on reducing the dependency on conventional energy sources. Focusing on the Gulf region, primarily in Saudi Arabia, high amounts of energy are consumed by the air conditioning and refrigeration applications. According to a report from 2010 [3] the amount of electrical energy consumed by the air conditioning sector in KSA was more than $36 \%$ of the total generated electricity, moreover this demand for energy is increasing. Hence we should try to satisfy these energy requirements in the air conditioning sector by the utilization of the renewable energy i.e. primarily by solar energy. The advantage of solar energy is that the peak demand for air conditioning matches with the peak of solar energy radiation [4]. Hepbasli and Alsuhaibani [5] carried out research reviewing the various applications and studies on solar energy in Saudi Arabia. Research in various applications has been carried out in Saudi Arabia. These include solar water desalination, solar powered irrigation, solar photovoltaic systems, solar stills, exergetic solar radiation and also some studies in solar cooling/refrigeration etc. However, less studies has been made for utilization of solar absorption systems for providing air conditioning in Saudi Arabia.

A project to reduce the cost and improve the efficiency of air cooling system was carried out by SOLARES in which Saudi Arabia participated. [6, 7]. Solar cooling can have a huge impact in Saudi Arabia and hence the number of projects for development and demonstration in this field should be increased. A variety of different solar refrigeration technologies have been developed and are now available at comparatively cheaper prices [8]. Two kinds of system can be used to produce cooling: solar thermal and solar electrical cooling systems. In the case of solar electrical system, photovoltaic system is used to obtain electrical energy from solar energy, which is then used to produce the refrigeration like the conventional vapor compression system. In the case of solar thermal system, solar energy is used to run the absorption refrigeration system. According to a study by Kim and Ferreira [8] solar thermal systems are cheaper than solar electrical systems. Another study by Otanicar et al. [9] shows that up to 95\% of incident solar radiation can be utilized by solar thermal systems compared to up to $35 \%$ of the incident solar radiation that is converted to electrical energy by photovoltaic system. Therefore, solar thermal systems have potential in producing the required cooling and more research is being done on this field; however, they have some challenges. A recent research paper by Siddiqui and Said [10] reviewed solar absorption systems and summarized the works done in this field. 


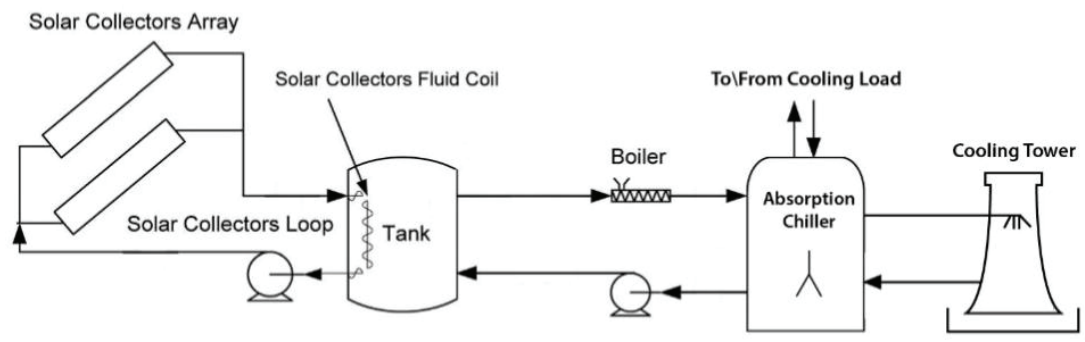

FIG. 1. SCHEMATIC DRAWING OF SOLAR POWERED ABSORPTION CHILLER SYSTEM

Some of the previous studies on solar absorption systems were carried out by Trombe and Foex [11] and Chinnappa [12]. Research was carried out by Kundu et al. [13] to study the performance of solar absorption systems using different types of solar collectors and the conclusion was made that the concave parabolic collector provided the best performance. Later, many components were added to absorption system to increase its $\mathrm{COP}$ (coefficient of performance). Aqua-ammonia and $\mathrm{LiBr}-$ water are the most common working pairs in the absorption refrigeration systems [10]. Various experimental and simulation studies showed that single effect and double effect solar powered absorption chiller have COP of around .7 and 1.3 respectively [14-17] with double effect chillers being cheaper by $50 \%$ for the same COP [18].

Florides et al. [19] carried out the simulation to study the performance of $\mathrm{LiBr}-$ water system in Cyprus. The system was equipped with $15 \mathrm{~m}^{2}$ compound parabolic collector and also consisted a $600 \mathrm{~L}$ hot water storage tank. For this system he also performed the cost optimization. Their optimization results indicated a life cycle savings of $\mathrm{C} £$ 1376 without subsidized fuel cost. Fumo et al. [20] studied a hypothetical solar thermal driven cooling system for data center in Albuquerque, New Mexico. Their results suggest using flat plat collectors are superior to evacuated tubes. In their conclusion the researchers suggest using the system in typical office building operating ( 8 am to $5 \mathrm{pm}$ ) and they expect that the system will have better energy performance.

Eicker and Pietruschka [21] performed the cost analysis of solar powered $\mathrm{LiBr}$-water absorption system for office buildings. Their cost analysis indicated that for long operation hours in Southern European locations, cooling costs are around 200 euros per MWh. They prepared a full simulation model of the absorption cooling system along with storage tank and collector model. Their results revealed that varying the load time 
for same maximum cooling load results in a variation of solar collector area by more than a factor of 2 for getting the same solar fraction.

The literature review revealed that there are limited studies on solar-driven absorption chiller for office buildings. However, no study has been conducted for such system in office building for Saudi Arabia weather conditions. Therefore, this study will fulfil this gap.

\section{SYSTEM DESCRIPTION}

For this study, an office building will be considered. The building's air conditioning system will run for 5 days a week. The cooling load of the building is satisfied with vapor compression air conditioning system having a $\mathrm{COP}$ of 4 . This vapor compression system also works as a heat pump when heating is required in the building with a COP of 3 .

TABLE 1. SPECIFICATIONS OF THE MODEL

\begin{tabular}{|c|c|c|c|c|c|}
\hline Parameter & $\begin{array}{l}\text { Magnitu } \\
\text { de }\end{array}$ & Units & Parameter & $\begin{array}{l}\text { Magnitud } \\
\mathrm{e}\end{array}$ & Units \\
\hline $\begin{array}{l}\text { Tank solar collector } \\
\text { coil effectiveness }\end{array}$ & 0.8 & & $\begin{array}{l}\text { Chiller heat } \\
\text { medium inlet } \\
\text { temperature }\end{array}$ & 88 (190) & ${ }^{\circ} \mathrm{C}\left({ }^{\circ} \mathrm{F}\right)$ \\
\hline Boiler efficiency & 0.8 & & $\begin{array}{l}\text { Chiller heat } \\
\text { medium outlet } \\
\text { temperature }\end{array}$ & 83 (181) & ${ }^{\circ} \mathrm{C}\left({ }^{\circ} \mathrm{F}\right)$ \\
\hline $\begin{array}{l}\text { Chiller nominal } \\
\text { cooling capacity }\end{array}$ & $35(10)$ & $\begin{array}{r}\mathrm{kW} \\
\text { (Ton) }\end{array}$ & $\begin{array}{l}\text { Heating water } \\
\text { mass flow rate }\end{array}$ & 2.4 & $\mathrm{~kg} / \mathrm{s}$ \\
\hline $\begin{array}{l}\text { Absorption chiller } \\
\text { cooling COP }\end{array}$ & 0.7 & & $\begin{array}{l}\text { Absorption Chiller } \\
\text { ump }\end{array}$ & 210 & W \\
\hline $\begin{array}{l}\text { Chiller nominal } \\
\text { heating capacity }\end{array}$ & $48.5(14)$ & $\begin{array}{r}\mathrm{kW} \\
\text { (Ton) }\end{array}$ & $\begin{array}{l}\text { Cooling tower } \\
\text { onsumption }\end{array}$ & 1500 & W \\
\hline $\begin{array}{l}\text { Absorption chiller } \\
\text { heating COP }\end{array}$ & 0.97 & & & & \\
\hline
\end{tabular}




\begin{tabular}{|c|c|c|c|c|c|}
\hline $\begin{array}{l}\text { Solar collectors } \\
\text { azimuth angle }\end{array}$ & $\begin{array}{l}0 \\
\text { Latitude } \\
\text { of the } \\
\text { selected } \\
\text { city }\end{array}$ & degree & & & \\
\hline \multicolumn{3}{|c|}{ Flat-plate solar collectors } & \multicolumn{3}{|c|}{ Evacuated Tube Collectors } \\
\hline FR $(\tau \alpha)$ & 0.726 & $\begin{array}{c}\mathrm{W} /( \\
\left.{ }^{\circ} \mathrm{Cm}^{2}\right)\end{array}$ & FR $(\tau \alpha)$ & .55 & $\begin{array}{c}\mathrm{W} /( \\
\left.{ }^{\circ} \mathrm{Cm}^{2}\right)\end{array}$ \\
\hline FR ( UL) & 3.35 & $\begin{array}{r}\mathrm{W} /( \\
\left.{ }^{\circ} \mathrm{Cm}^{2}\right)\end{array}$ & FR ( UL) & 1.71 & $\begin{array}{l}\mathrm{W} /( \\
\left.{ }^{\circ} \mathrm{Cm}^{2}\right)\end{array}$ \\
\hline Collector gross area & 12.5 & $\mathrm{~m}^{2}$ & $\begin{array}{l}\text { Collector gross } \\
\text { area }\end{array}$ & 4.6 & $\mathrm{~m}^{2}$ \\
\hline $\begin{array}{l}\text { Collector mass flow } \\
\text { rate }\end{array}$ & 0.0161 & $\mathrm{~kg} / \mathrm{s}$ & $\begin{array}{l}\text { Collector mass } \\
\text { flow rate }\end{array}$ & .0161 & $\mathrm{~kg} / \mathrm{s}$ \\
\hline $\begin{array}{l}\text { Storage Capacity / } \\
\text { Solar Collector } \\
\text { Area }\end{array}$ & 75 & $\mathrm{~L} / \mathrm{m}^{2}$ & $\begin{array}{l}\text { Storage Capacity / } \\
\text { Solar Collector } \\
\text { Area }\end{array}$ & 75 & $\mathrm{~L} / \mathrm{m}^{2}$ \\
\hline $\begin{array}{l}\text { Number of Solar } \\
\text { Collectors }\end{array}$ & $\begin{array}{c}(2,4,8,12 \\
, 16,20)\end{array}$ & $\begin{array}{l}\text { variabl } \\
\text { e }\end{array}$ & $\begin{array}{l}\text { Number of Solar } \\
\text { Collectors }\end{array}$ & $\begin{array}{c}(10,20,4 \\
0,60,80,1 \\
00)\end{array}$ & variable \\
\hline
\end{tabular}

However, during the peak cooling load excess electricity is consumed which transfers into high demand on the electricity grid. Also, for meeting the peak summer cooling demand the cooling system of a much higher capacity is required, compared to the capacity of the cooling system throughout the year. Therefore, introducing a solar powered absorption chiller to support at peak cooling loads to minimize the cooling required from the vapor compression system is considered to be a good option. The solar powered absorption chiller will be investigated when being run by two different types of solar collectors: flat plate collectors and evacuated tube collectors. The system consists of solar collectors, storage tank with a heat exchanger, an auxiliary natural gas boiler to provide the required inlet temperature to the absorption chiller, and a cooling 
tower for cooling the condenser coils of the absorption chiller. Chilled water from the absorption chiller is pumped to the air conditioning distribution system. Figure 1 shows the schematic diagram for the system under study.

\section{Cooling and Heating Loads}

The absorption chiller is assumed to be working at steady state condition and provide constant full capacity cooling or heating power for various cases at the specified duration of operation. When the average temperature of the month is above $20^{\circ} \mathrm{C}$, the absorption chiller system will operate during peak cooling demand of the office building, the absorption chiller is assumed to provide a constant 10 Ton of cooling, and the rest will be met by the conventional cooling system which also satisfies the cooling demand during the remaining hours of the day. Study has been made for 3 scenarios of peak load durations namely 4,6 , and 8 hours.

Similarly when the average temperature of the month is below $20^{\circ} \mathrm{C}$, the absorption chiller system will operate during peak heating demand of the office building, the absorption chiller is assumed to provide a constant 14 Ton of heating, and the rest will be met by the conventional heating system which also satisfies the heating demand during the remaining hours of the day. Study has been made for 3 scenarios of peak load durations namely 4,6 , and 8 hours.

\section{Location Selected}

Six cities from different provinces in KSA were chosen. The cities and their metrological data are presented as follows.

TABLE 2. SELECTED CITIES AND THEIR LOCATIONS

City Abha Dhahran Hail Jeddah Nejran Riyadh




\section{Locati $18^{\circ} 13^{\prime} \mathrm{N} 42^{\circ} 26^{\circ} 16^{\prime} \mathrm{N} 50^{\circ} 27^{\circ} 31^{\prime} \mathrm{N} 41^{\circ} 21^{\circ} 32^{\prime} \mathrm{N} 39^{\circ} 17^{\circ} 29^{\prime} \mathrm{N} 4424^{\circ} 38^{\prime} \mathrm{N} 46^{\circ} 4$ on $\quad 30^{\prime} \mathrm{E} \quad 0^{\prime} \mathrm{E} \quad 41^{\prime} \mathrm{E} \quad 1^{\prime} \mathrm{E} \quad{ }^{\circ} 7^{\prime} \mathrm{E} \quad 3^{\prime} \mathrm{E}$}

All data in this section were obtained from weather data obtained from NASA through RetScreen Software [22]. Figure 2 shows the general curve of ambient air temperature for all cities. Hail city has the lowest ambient temperatures during the winter; therefore, it is recommended that peak load heating is mostly required for this area. Its average temperatures are around 15 degrees Celsius in winter. Jeddah on the other hand has the lowest temperature deviations between summer and winter with average temperatures are around $25^{\circ} \mathrm{C}$ in winter and around 31 degrees in summer. Hence it does not require heating throughout the year. However, the summer peak daily average temperatures are in Riyadh and Dhahran with temperatures 35 and $36^{\circ} \mathrm{C}$ respectively. This peak suggest that peak load cooling is mostly needed in these two cities. On the other hand, during summer Abha has the lowest ambient temperature among all cities with an average temperature of around $22^{\circ} \mathrm{C}$. This suggests that Abha requires the least peak load cooling.

Figure 3 shows the daily Horizontal solar radiation in $\mathrm{kWh} / \mathrm{m}^{2} / \mathrm{d}$. Similar to the air temperature curve, the solar radiation curve has a maximum in summer and minimum in winter for all cities, Nejran is closer to the equator and, hence, has the highest peaks in summer as well as winter with average values around $7.5 \mathrm{kWh} / \mathrm{m}^{2} / \mathrm{d}$ during summer and $6.4 \mathrm{kWh} / \mathrm{m}^{2} / \mathrm{d}$ during winter. During the summer Abha and Riyadh has the lowest peaks of solar radiation with average values around $5.6 \mathrm{kWh} / \mathrm{m}^{2} / \mathrm{d}$. Hence Abha has the least potential to use solar energy compared to the other cities during summer. During the winter the three locations with lowest radiation are Dhahran, Hail and Riyadh with average values around $4.3 \mathrm{kWh} / \mathrm{m}^{2} / \mathrm{d}$. Thus, these areas are less suitable for solar energy application in winter. However during the summer, Dhahran and Jeddah have Radiation values on the higher side with average values around $6.85 \mathrm{kWh} / \mathrm{m}^{2} / \mathrm{d}$. Hence during summer these areas are more feasible for solar energy.

\section{ENERGY ANALYSIS}

Cooling and heating air conditioning loads from the office building were transformed into hot water load or demand by dividing the load by its corresponding absorption chiller COP. Then, hot water demand is entered into RetScreen, with different combinations of cities, number and type of solar collectors, number of operational hours. The input variables into the energy analysis were given in Table 1. The following 
values of solar fraction were obtained as illustrated in Table 3 . The results indicate the number of flat plate solar collectors and evacuated tube solar collectors required to achieve solar fraction 1 for various operating hours for different cities.

For the case of flat plate collectors for 4 hours of operation for all cities approximately 12 collectors are required. In case of 6 hours of operation at-least 16 collectors are required and for 8 hours of operation more than 20 collectors are required. When evacuated tube collectors are used for 4, 6, and 8 hour operations approximately 40, 60, and 80 collectors are required for achieving solar fraction of 1 , that is, for operating the absorption chiller independently by solar thermal energy only.

The results clearly shows that flat plate collectors are superior to evacuated tubes in terms of delivering the required energy for this specific application. This coincides with the findings of Fumo et al. [20], and the reason is that since the temperature rise in the collectors are small, around $5^{\circ} \mathrm{C}$ only, flat plate collector's efficiency is higher for that range. Another observation in the data is that Nejran, with the lowest latitude, has the highest solar fraction, then Jeddah, Riyadh, and Dhahran which have similar intermediate latitude have similar values of solar fraction. Finally, Hail city, the city with the highest latitude has the lowest values of solar fraction. However, Abha is not included in that pattern due to its low temperatures and different cooling/heating demand pattern.

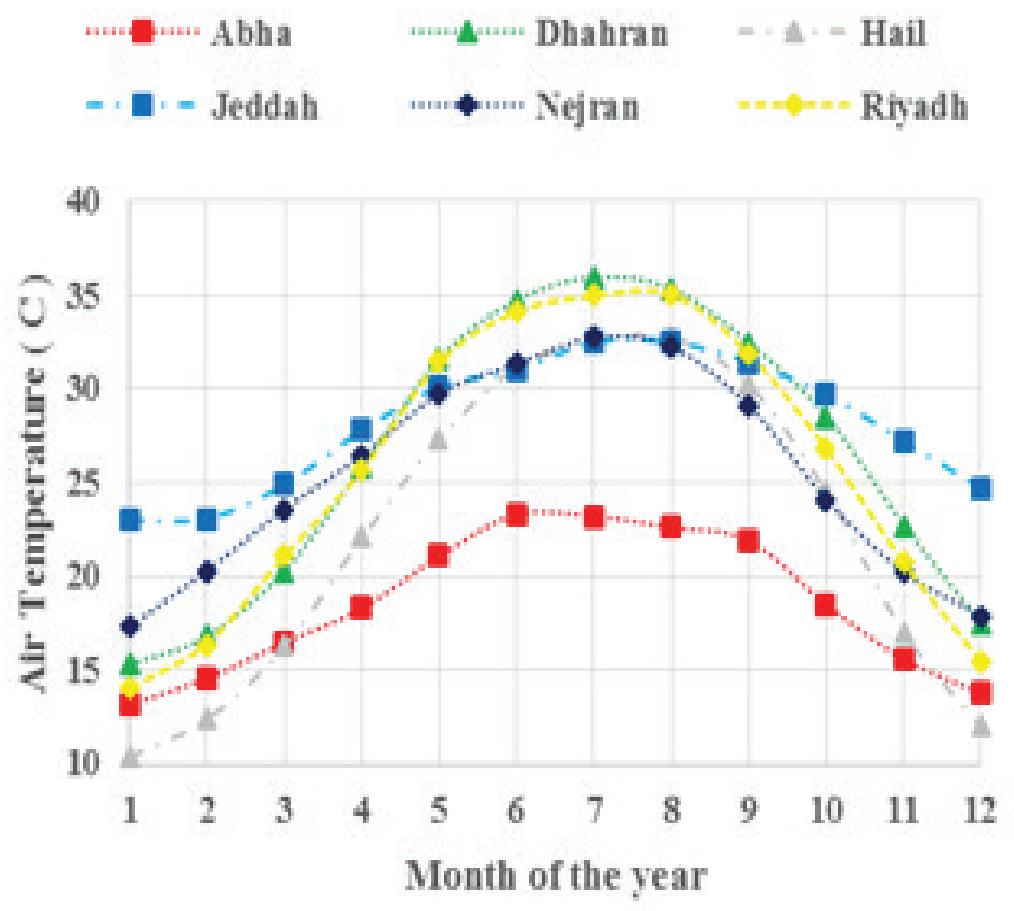




\section{FIG. 2. TEMPERATURE PROFILES}

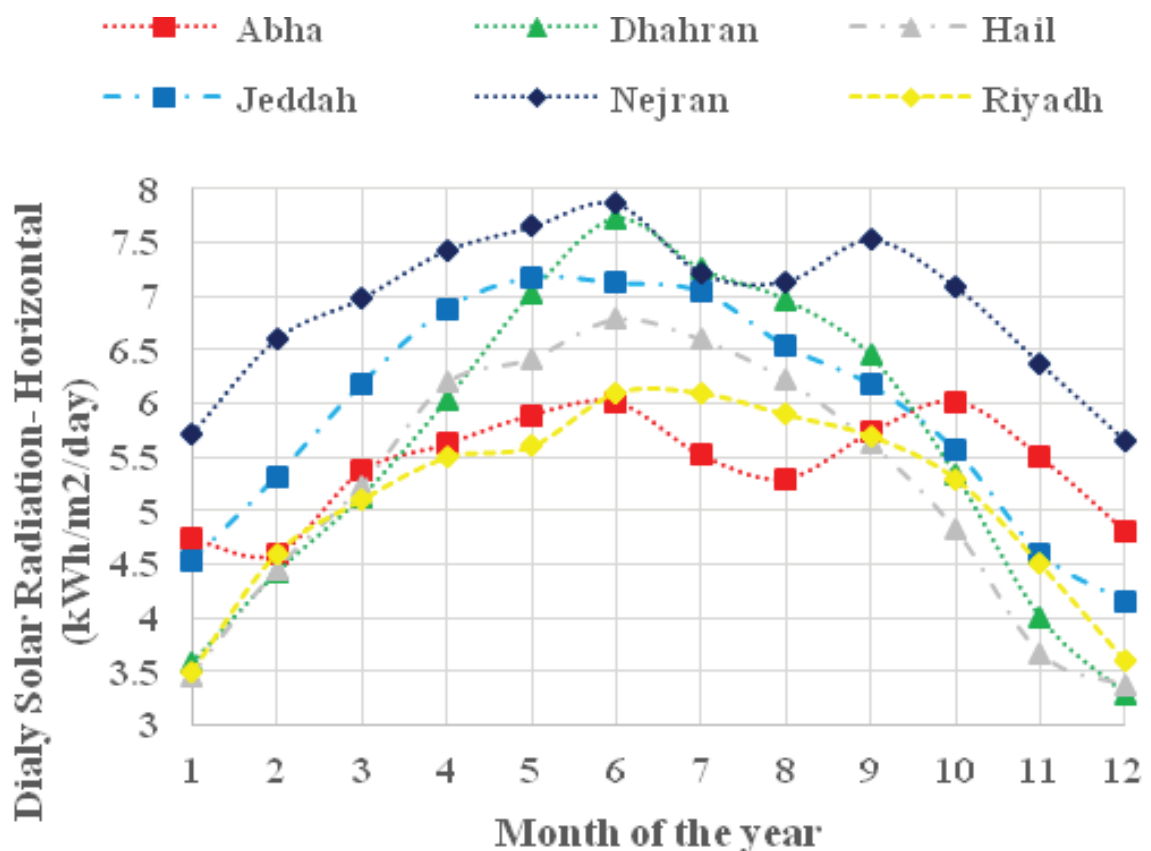

FIG. 3. SOLAR RADIATION PROFILES

TABLE 3. SOLAR FRACTION

\begin{tabular}{|c|c|c|c|c|c|c|c|c|c|c|c|c|c|c|c|c|c|c|c|}
\hline \multirow{8}{*}{ 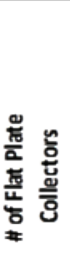 } & & \multicolumn{3}{|c|}{$\begin{array}{c}\text { Abha } \\
\text { Operating Hours }\end{array}$} & \multicolumn{3}{|c|}{$\begin{array}{c}\text { Dhahran } \\
\text { Operating Hours }\end{array}$} & \multicolumn{3}{|c|}{$\begin{array}{c}\text { Hail } \\
\text { Operating Hours }\end{array}$} & \multicolumn{3}{|c|}{$\begin{array}{c}\text { Jeddah } \\
\text { Operating Hours }\end{array}$} & \multicolumn{3}{|c|}{$\begin{array}{c}\text { Nejran } \\
\text { Operating Hours }\end{array}$} & \multicolumn{3}{|c|}{$\begin{array}{c}\text { Riyadh } \\
\text { Operating Hours } \\
\end{array}$} \\
\hline & & 4 & 6 & 8 & 4 & 6 & 8 & 4 & 6 & 8 & 4 & 6 & 8 & 4 & 6 & 8 & 4 & 6 & 8 \\
\hline & 2 & 0.24 & 0.17 & 0.13 & 0.27 & 0.19 & 0.15 & 0.24 & 0.17 & 0.13 & 0.30 & 0.21 & 0.16 & 0.37 & 0.26 & 0.26 & 0.28 & 0.20 & 0.12 \\
\hline & 4 & 0.43 & 0.31 & 0.24 & 0.47 & 0.34 & 0.27 & 0.43 & 0.31 & 0.24 & 0.51 & 0.37 & 0.30 & 0.60 & 0.46 & 0.46 & 0.48 & 0.36 & 0.23 \\
\hline & 8 & 0.75 & 0.54 & 0.43 & 0.76 & 0.57 & 0.47 & 0.74 & 0.53 & 0.43 & 0.79 & 0.61 & 0.51 & 0.87 & 0.71 & 0.71 & 0.78 & 0.59 & 0.42 \\
\hline & 12 & 1 & 0.75 & 0.59 & 1 & 0.76 & 0.62 & 1 & 0.74 & 0.58 & 1 & 0.79 & 0.66 & 1 & 0.87 & 0.87 & 1 & 0.78 & 0.57 \\
\hline & 16 & 1 & 0.98 & 0.75 & 1 & 0.98 & 0.76 & 1 & 0.97 & 0.74 & 1 & 0.99 & 0.79 & 1 & 1 & 1 & 1 & 0.99 & 0.72 \\
\hline & 20 & 1 & 1 & 0.93 & 1 & 1 & 0.92 & 1 & 1 & 0.91 & 1 & 1 & 0.94 & 1 & 1 & 1 & 1 & 1 & 0.89 \\
\hline \multirow{9}{*}{ 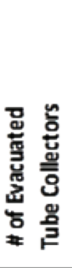 } & & \multicolumn{3}{|c|}{ Abha } & \multicolumn{3}{|c|}{ Dhahran } & \multicolumn{3}{|c|}{ Hail } & \multicolumn{3}{|c|}{ Jeddah } & \multicolumn{3}{|c|}{ Nejran } & \multicolumn{3}{|c|}{ Riyadh } \\
\hline & & \multicolumn{3}{|c|}{ Operating Hours } & \multicolumn{3}{|c|}{ Operating Hours } & \multicolumn{3}{|c|}{ Operating Hours } & \multicolumn{3}{|c|}{ Operating Hours } & \multicolumn{3}{|c|}{ Operating Hours } & \multicolumn{3}{|c|}{ Operating Hours } \\
\hline & & 4 & 6 & 8 & 4 & 6 & 8 & 4 & 6 & 8 & 4 & 6 & 8 & 4 & 6 & 8 & 4 & 6 & 8 \\
\hline & 10 & 0.43 & 0.31 & 0.24 & 0.46 & 0.34 & 0.26 & 0.43 & 0.31 & 0.24 & 0.50 & 0.36 & 0.28 & 0.59 & 0.44 & 0.34 & 0.42 & 0.30 & 0.24 \\
\hline & 20 & 0.68 & 0.53 & 0.43 & 0.71 & 0.57 & 0.46 & 0.67 & 0.53 & 0.43 & 0.75 & 0.60 & 0.50 & 0.84 & 0.70 & 0.59 & 0.66 & 0.52 & 0.42 \\
\hline & 40 & 0.92 & 0.78 & 0.68 & 0.93 & 0.80 & 0.71 & 0.91 & 0.77 & 0.67 & 0.95 & 0.84 & 0.75 & 1 & 0.91 & 0.84 & 0.90 & 0.76 & 0.66 \\
\hline & 60 & 1 & 0.92 & 0.81 & 1 & 0.93 & 0.84 & 1 & 0.91 & 0.81 & 1 & 0.95 & 0.87 & 1 & 1 & 0.94 & 1 & 0.90 & 0.80 \\
\hline & 80 & 1 & 1 & 0.92 & 1 & 1 & 0.93 & 1 & 1 & 0.91 & 1 & 1 & 0.95 & 1 & 1 & 1 & 1 & 1 & 0.90 \\
\hline & 100 & 1 & 1 & 1 & 1 & 1 & 1 & 1 & 1 & 1 & 1 & 1 & 1 & 1 & 1 & 1 & 1 & 1 & 1 \\
\hline
\end{tabular}

\section{ECONOMIC ANALYSIS}

Riyadh was selected as the city to make the detailed economic analysis because it is the capital and has the highest number of office buildings. Additionally, resources and their 
availability is high. Finally, since it has similar cooling/heating demand as Dhahran and it also has similar solar fraction, it is expected that the economic analysis for both cities will be very close to each other. Table 4 lists the main inputs used for the 25 years economic analysis of the project. Natural Gas prices and electricity prices are today's prices for commercial sector. The Net Present Value (NPV) for the project in Riyadh are given in figures 4 and 5 below for flat plate collectors and evacuated tube collectors respectively for three different running time. The results from the figures clearly indicate that it is feasible to run the absorption chiller with natural gas instead of having vapor compression system since it has positive NPV at 0 Collectors. In addition, the introduction of solar collectors is not economically feasible because it decreases the NPV of the project as number of collectors is increased. However, another observation made from comparing the figures indicate that utilization of flat plate collectors are more feasible than evacuated tube collectors. Also it is shown that the longer the time the absorption chiller runs per day, the more economical it becomes.

The results indicate that using 20 flat plate solar collectors for 8 hour operation of absorption chiller has a positive NPV, and hence is economically feasible. But as the number of hours of operation are decreased the NPV becomes negative. Utilizing up to 12 flat plate collectors for all 3 durations of operation has a positive NPV, hence with lower number of collectors the operation is feasible. For evacuated tube collectors, utilizing more than 20 collectors results in a negative NPV, hence evacuated tube solar collectors are not economically feasible. The low prices of natural gas and electricity and the high initial cost of solar collectors are the key elements for this result of NPV. To make this system feasible many approaches may be taken. An increase in fuel prices, introduction of greenhouse emissions tax, a subsidy in the collectors prices are only few of many other possible governmental solutions. However, from consumer point of view, running the system for longer periods of time, 7-days a week will make the project more feasible. Another possible approach is the use of two stage absorption chillers which will lead to higher NPV. 


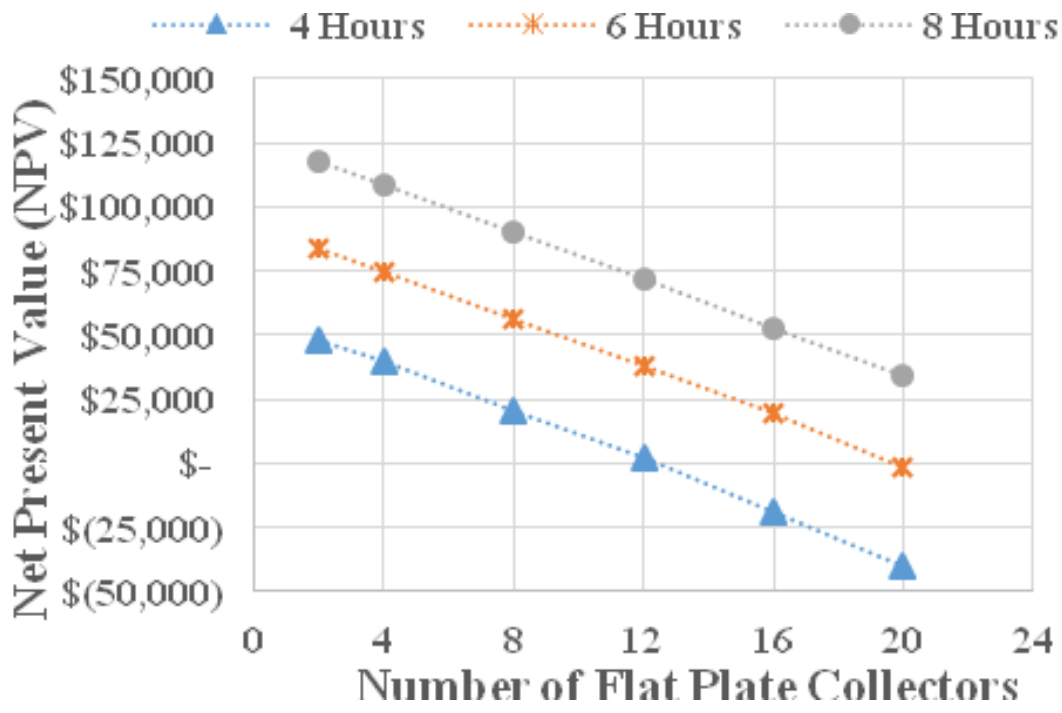

FIG. 4. NPV OF FLAT PLATE COLLECTORS

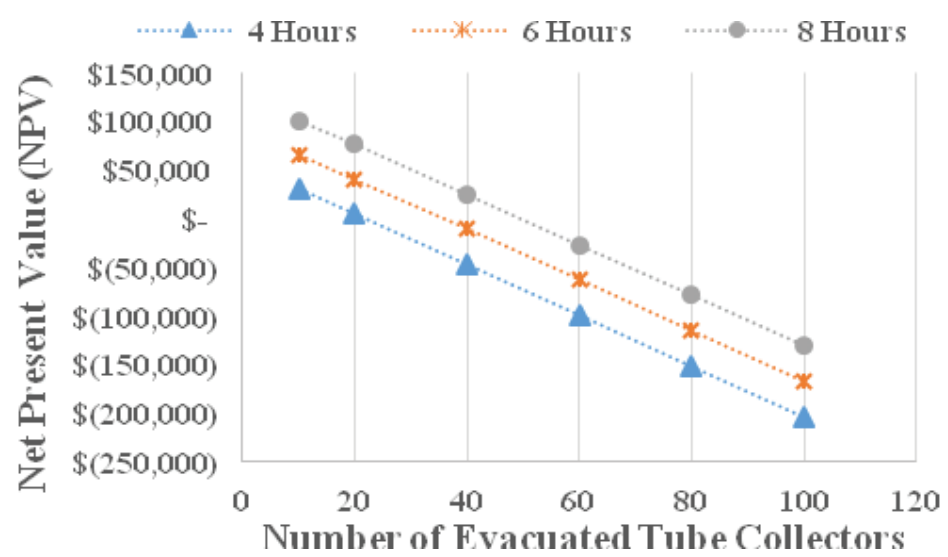

FIG. 5. NPV OF EVACUATED TUBE COLLECTORS

TABLE 4. ECONOMIC ANALYSIS ASSUMPTIONS

\begin{tabular}{|lcl|}
\hline Initial Costs & $\begin{array}{c}\text { Unit } \\
\text { price }\end{array}$ & Units \\
\hline
\end{tabular}




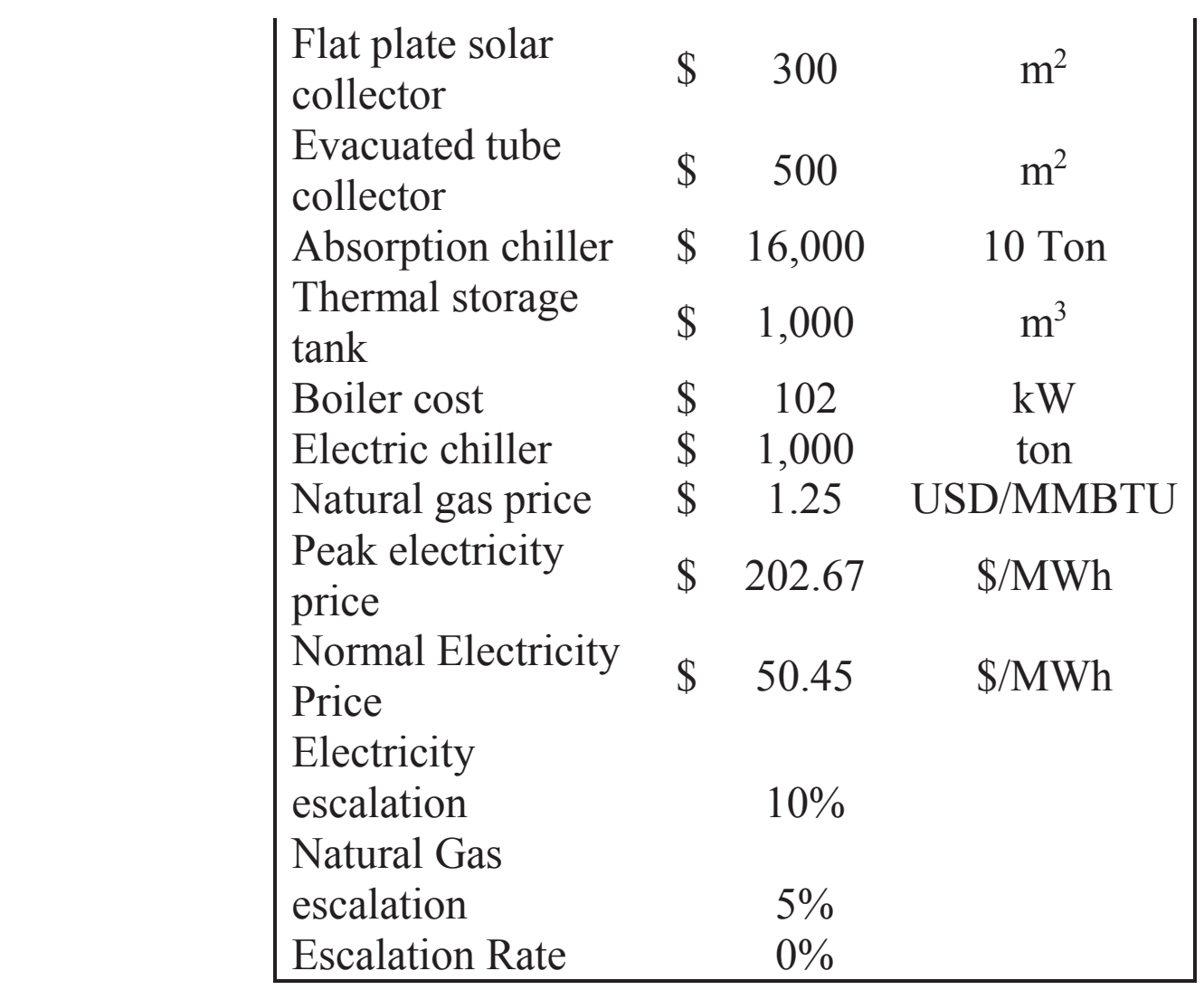

\section{CONCLUSION}

This study presents results by performing simulations with different arrangements of solar thermal driven cooling systems as a cooling plant in order to reduce the peak cooling and heating loads in office buildings in Saudi Arabia. The different arrangements considered were the number of collectors, type of collectors, and different duration of operation during the day when the peak cooling load is required varying from 4 to 8 hours. Flat plate collectors and evacuated tube collectors were compared. Our results with energy analysis suggests that flat plate collectors are better than evacuated tube collectors in terms of delivering the required energy for the office building with electric chillers since that temperature rise in the collectors are small, around $5^{\circ} \mathrm{C}$ only, flat plate collector's efficiency is higher for that range. With increasing the number of operation hours the number of collectors required also increases to have the same solar fraction. Also the results from economic analysis suggest that while proposing a gas fired absorption chiller will reduce running costs, further reduction by using solar collectors is not feasible because of its high initial cost. At the best case scenario NVP of a 10 Ton Absorption chiller operated by natural gas boiler and 2 large flat plate collectors $\left(12 \mathrm{~m}^{2}\right.$ each) running for 8 hours/day, 5 days/week has a value of $117,000 \$$ and Internal Rate of Return IRR of $12 \%$. Using solar collector for the absorption chiller can be more feasible solution if it used for seven days a week 
rather than five days a week. Further significant reduction in solar collectors prices and/or increase in the fossil fuel prices, will make solar driven cooling system a feasible alternative. Finally, government economic incentives and taxes can serve as a boost for the feasibility of such projects.

\section{REFERENCES}

[1] Solanki, C. S., .Solar Photovoltaic Technol. Syst. 2013;1:23-4.

[2] Balaras, C. A., Grossman, G., Henning, H-M., Infante Ferreira, C. A., Podesser, E., Wang, L., and Wiemken, E., 2007, "Solar Air Conditioning in Europe - an Overview," Renewable and Sustainable Energy Reviews, 11(2), pp. 299-314.

[3] Ministry of Water \& Electricity, KSA annual report; 2010.

[4] Said, S. A. M., Habib, M. A., and Iqbal, M. O., 2003, "Database for Building Energy Prediction in Saudi Arabia,” Energy Conversion and Management, 44(1), pp. 191-201.

[5] Hepbasli, A., and Alsuhaibani, Z., 2011, "A Key Review on Present Status and Future Directions of Solar Energy Studies and Applications in Saudi Arabia," Renewable and Sustainable Energy Reviews, 15(9), pp. 5021-5050.

[6] SAW, Saudi Aramco World. A solar village. September/October print edition; 1981. p. 16-29.

[7] Vincent-Barwood A. A solar village. Saudi Arabia and solar energy - a special section; 2011.http://www.saudiaramcoworld.com/

issue/198105/saudi.arabia.and.solar.energy.a.special.section.html

[8] Kim, D. S., and Infante Ferreira, C. A., 2008, "Solar Refrigeration Options - a State-of-the-Art Review," International Journal of Refrigeration, 31(1), pp. 3-15. 
[9] Otanicar, T., Taylor, R. A., and Phelan, P. E., 2012, "Prospects for Solar Cooling - an Economic and Environmental Assessment," Sol. Energy, 86(5), pp. 1287-1299.

[10] Siddiqui, M. U., and Said, S. A. M., 2015, "A Review of Solar Powered Absorption Systems," Renewable and Sustainable Energy Reviews, 42, pp. 93-115.

[11] Trombe, F., and Foex, M., 1957, "The Production of Cold by Means of Solar Radiation," Sol. Energy, 1(1), pp. 51-52.

[12] Chinnappa, J. C. V., 1962, "Performance of an Intermittent Refrigerator Operated by a Flat-Plate Collector,” Sol. Energy, 6(4), pp. 143-150.

[13] Kundu, B., Mondal, P. K., Datta, S. P., and Wongwises, S., 2010, “Operating Design Conditions of a Solar-Powered Vapor Absorption Cooling System with an Absorber Plate having Different Profiles: an Analytical Study," Int. Commun. Heat Mass Transfer, 37(9), pp. 1238-45.

[14] Raghuvanshi, S., and Maheshwari G., 2011, "Analysis of Ammonia-Water (NH3-H2O) Vapor Absorption Refrigeration System Based on First Law of Thermodynamics," Int. J. Sci. Eng. Res., 2(8), pp. 1-7.

[15] Gomri, R., 2009, "Second Law Comparison of Single Effect and Double Effect Vapour Absorption Refrigeration Systems," Energy Conversion and Management, 50(5), pp. 1279-1287.

[16] Balghouthi, M., Chahbani, M. H., and Guizani, A., 2005, "Solar Powered Air Conditioning as a Solution to Reduce Environmental Pollution in Tunisia," Desalination, 185(1-3), pp. 105-110.

[17] Balghouthi, M., Chahbani, M. H., and Guizani, A., 2008, "Feasibility of Solar Absorption Air Conditioning in Tunisia," Building and Environment, 43(9), pp. 1459-1470.

[18] Sumathy, K., Huang, Z. C., and Li, Z. F., 2002, "Solar Absorption Cooling with Low Grade Heat Source - a Strategy of Development in South China," Solar Energy, 72(2), pp. 155-165.

[19] Florides, G. A., Kalogirou, S. A., Tassou, S. A., and Wrobel, L. C., 2002, "Modelling and Simulation of an Absorption Solar Cooling System for Cyprus," Solar Energy, 72(1), pp. 43-51.

[20] Fumo, N., Bortone, V., and Zambrano, J. C., 2011, "Solar Thermal Driven Cooling System for a Data Center in Albuquerque New Mexico,” ASME. J. Sol. Energy Eng., 133(4), pp. 041008-0410087.

[21] Eicker, U., and Pietruschka, D., 2009, "Design and Performance of Solar Powered Absorption Cooling Systems in Office Buildings," Energy and Buildings, 41(1), pp. 81-91.

[22] N. R. C. E. S. C. E. T. C. - V. Rets. I. Government of Canada, "RETScreen International Climate data." 